\title{
福建闽江水口水库凤眼莲空间分布特征及其动态”
}

\author{
陈 潇, 潘文斌 ${ }^{* *}$ 王 牧
}

(福州大学环境与资源学院,福州 350108)

\begin{abstract}
摘 要: 为研究闽江水口水库凤眼莲空间分布特征及动态变化,根据 2001-2009 年水口库区无云覆盖的 24 幅卫星遥感 影像, 构建研究区域凤眼莲干流一支流分布的空间结构, 并通过建立端元的混合象元线性分解模型, 对福建省水口水库不 同时间、不同区域的凤眼莲分布特征进行系统分析,结果表明,随着时间的推移, 凤眼莲的暴发区逐渐向下游迁移, 同时, 支流对研究区域凤眼莲的面积有重要影响, 特别是河流较长、周边有人口居住的支流是凤眼莲源头治理的重点; 各种人 为或自然原因造成的水体富营养化、河流流速变缓等是凤眼莲泛滥的重要原因. 建议针对研究区域上游及其周边进行养 殖污染、工业污染整治, 强化对污染源的监督管理,推进生态环境建设与保护, 建设生态功能保护区等. 本研究可为了解 水口水库的凤眼莲时空分布规律,进而制定相应的预防与控制管理措施提供必不可少的数据基础和理论依据.
\end{abstract}

关键词: 凤眼莲;水口水库;空间分布特征及其动态

\section{Spatial distribution characteristics and dynamics of Eichhornia crassipes in the Shuikou Reservoir, Fujian Province}

\author{
CHEN Xiao, PAN Wenbin \& WANG Mu \\ (College of Environment and Resources, Fuzhou University, Fuzhou 350108, P. R. China)
}

\begin{abstract}
In order to study the spatial distribution characteristics and dynamics of Eichhornia crassipes in the Shuikou Reservoir, this study, using 24 unclouded remote sensing satellite images from 2001 to 2009 which covered the Shuikou Reservoir region, reconstructed the spatial structure of Eichhornia crassipes distributed in the mainstream and tributaries, and analyzed the situation of Eichhornia crassipes in the Shuikou Reservoir at different times and different observation zones according to the Linear Spectral Mixture Analysis Method. The results indicate that the outbreak area of Eichhornia crassipes moves from the upper reaches to the lower reaches gradually as time goes on. And some long tributaries with high riparian populations played an important role in the contribution of Eichhornia crassipes in this survey region. The significant factors about the fast growth of Eichhornia crassipes included water eutrophication, low velocity, etc. . It is suggested that local government should take actions to fight against the pollution from the industry, aquaculture, and poultry farming in this area, enhance the supervision and protection of ecological environment, and establish nature reserves. This study can enhance the understanding of the temporal and spatial distributions of Eichhornia crassipes, and then provide fundamental data and theory for managing and controlling the nuisance plants.
\end{abstract}

Keywords: Eichhornia crassipes; Shuikou Reservoir; spatial distribution characteristics and dynamics

凤眼莲,拉丁名 Eichhornia crassipes (Water Hyacinth), 原产于南美的巴西东北部, 属雨久花科,它还有许 多俗名,如水葫芦、凤眼蓝、水凤仙、水风信子等. 凤眼莲现广泛分布于北美、亚洲、大洋洲和非洲等众多国 家, 是目前世界上危害最严重的水生漂浮植物, 被列为世界十大害草之一 ${ }^{[1]} .1901$ 年风眼莲作为观赏植物 引人中国, 1950s 开始在我国南方地区作为畜命饲料栽培, 由于繁殖速度极快, 又几乎没有竞争对手和天敌, 易在生长区内形成优势物种, 目前已在我国南方多处水域发生风眼莲种群大暴发事件. 福建位于全国东南 部, 其温暖潮湿的气候利于外来物种 ( 凤眼莲)生长繁殖. 近年来凤眼莲在江河、水库泛滥成灾, 致使水质恶 化, 水生动植物大量死亡, 并严重影响行洪排涝、航运、灌溉、发电、水产养殖及旅游, 给社会、经济带来巨大

* 2011-06-09 收稿;2011-09-25 收修改稿. 陈潇,女,1986 年生,硕士研究生;E-mail:amethyst_cx@ 126. com.

** 通信作者;E-mail:WenbinPan@fzu. edu. cn. 
损失 ${ }^{[2-3]}$. 本文研究区水口库区则是福建的重灾区之一.

在我国,关于人侵植物的分布研究基本采用野外采样及水质监测的方法,此方法要耗费大量时间以及 人力财力, 具体操作起来较为麻烦. 近年来, 随着遥感技术的快速发展, 科学家运用获得的各种卫星影像或 航片, 采取影像解释技术, 对人侵物种时空分布进行数字化研究, 如非洲的维多利亚湖、美国的格兰德河流 域、印度的班加罗尔地区等 ${ }^{[4-12]}$. 由于遥感影像的应用,学者们对大尺度下人侵植物时空分布进行数字化研 究已取得一定成绩,但在我国目前尚无学者用遥感手段对凤眼莲进行面积统计和变化监测. 本文使用卫星 遥感影像数据 (CEBERS CCD、LANDSAT TM/ETM +), 通过建立端元的混合象元线性分解模型, 同时结合该 地区凤眼莲新闻报告的资料,构建其干流支流分布的空间结构,针对福建省水口水库不同时间、区域的凤 眼莲分布特征进行系统分析,其研究结果可为水口水库的污染和治理提供一定的理论依据.

\section{1 材料和方法}

\section{1 研究区域概况}

水口水库位于闽江中下游的闽清县雄江镇下蹼村 $\left(26^{\circ} 18^{\prime} 7^{\prime \prime} \sim 26^{\circ} 38^{\prime} 25^{\prime \prime} \mathrm{N}, 118^{\circ} 10^{\prime} 44^{\prime \prime} \sim 118^{\circ} 48^{\prime} 48^{\prime \prime} \mathrm{E}\right.$ ), 库区跨越闽清县、古田县、尤溪县和南平市延平区. 水口水库 1993 年 3 月开始蓄水, 1996 年 11 月竣工, 为河 道型水库, 总库容 $26 \times 10^{8} \mathrm{~m}^{3}$, 库区主河道长 $94 \mathrm{~km}$, 面积约 $99.6 \mathrm{~km}^{2}$, 水库最大坝高 $101 \mathrm{~m}$, 坝顶高程 $74 \mathrm{~m}$, 是目前中国东南地区最大的水力发电站 ${ }^{[13]} .2002$ 年起闽江上游出现少雨干旱、气温偏高的气候现象, 上游 来水量减少,汛期水口大坝也基本没有开闸泄洪, 因此绝大部分库区上游漂流而下的凤眼莲被拦截在库内 兹生蔓延,且水口库区的水流缓慢, 给凤眼莲提供了快速生长的环境 ${ }^{[3]}$.

\section{2 技术路线}

研究基本思路和技术路线如图 1.

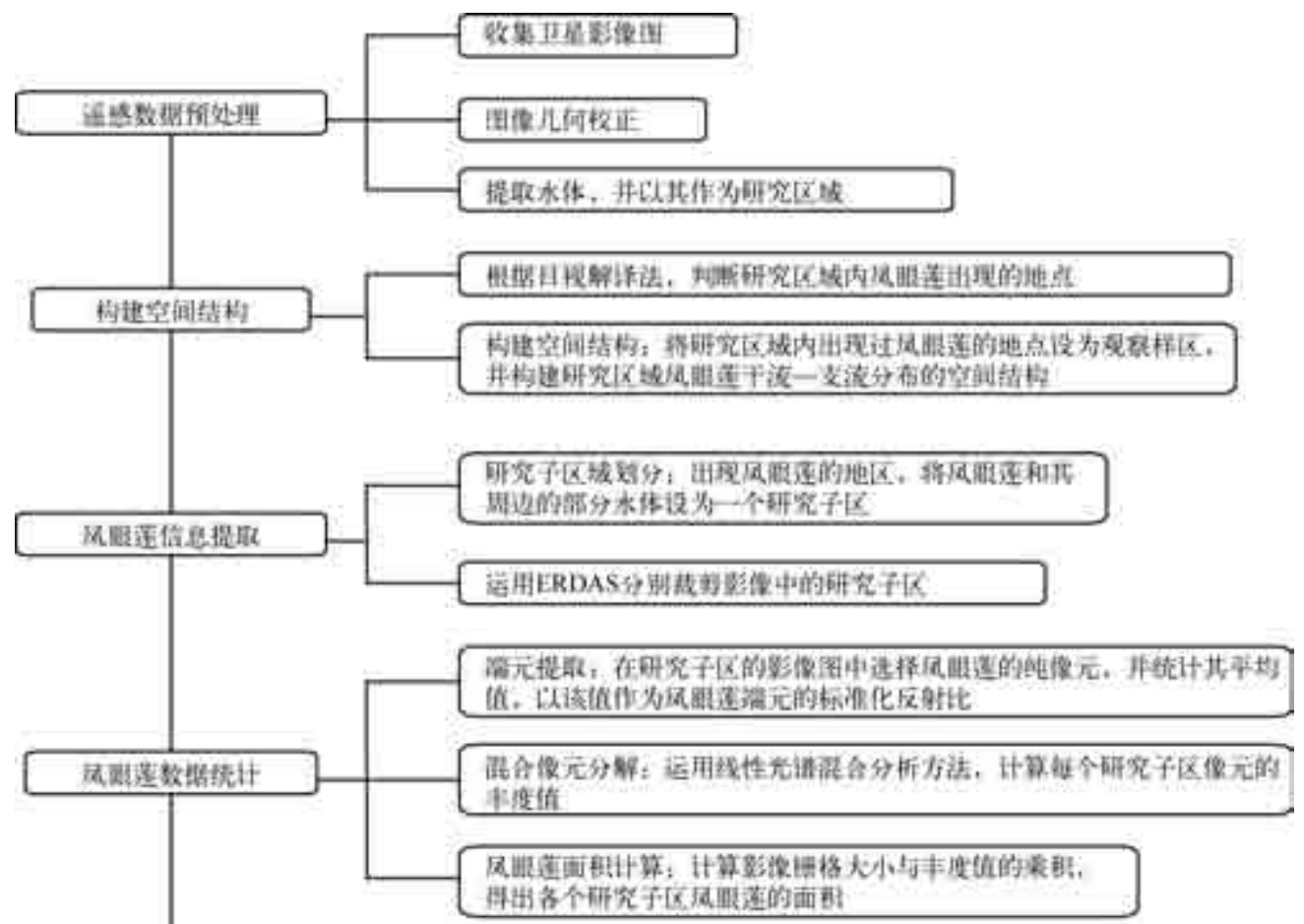

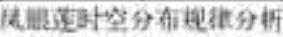

图 1 技术路线图

Fig. 1 Technology roadmapping 


\section{3 数据收集与样点布设}

共收集了 2001-2009 年水口水库天气状况良好的卫星遥感影像 24 幅, 其中 LANDSAT TM/ETM + 为 15 幅( 2001 年 1 月 2 日、2001 年 5 月 23 日、2002 年 3 月 7 日、 2002 年 5 月 26 日、2003 年 2 月 6 日、2003 年 3 月 26 日、2006 年 6 月 22 日、2006 年 9 月 26 日、2006 年 11 月 5 日、2007年 1 月 8 日、2007 年 5 月 8 日、2007 年 7 月 27 日、2007 年 9 月 13 日、2009 年 6 月 6 日、2009 年 7 月 16 日), CEBERS CCD 为 9 幅(2001 年 2 月 16 日、2005年 10 月 21 日、2003 年 12 月 18 日、2004 年 10 月 22 日、2004 年 12 月 16 日、2006 年 1 月 7 日、2006 年 6 月 12 日、2006 年 8 月 29 日、2007 年 8 月 13 日). 同时收集水口水库相关的新闻资料,对比当地拍摄的 照片, 发现水口库区内漂浮的都是凤眼莲, 因此, 本研究假设影像中河道内发现的水生植被均为凤眼莲.

运用 ERDAS 对卫星影像进行几何纠正及研究区域的水体提取. 基于研究区域卫星影像的不同地物 (水 体和凤眼莲) 的光谱特征, 选择 432 波段组合作为凤眼莲信息提取的模式. 将水口水库出现过凤眼莲的地点 设为观察区, 共将水口库区分为 8 个支流汇水区, 并将干流分成 7 段 (图 2), 其中 $\mathrm{G}$ 开头的点代表干流的观 察区, $\mathrm{Z}$ 开头的点代表支流的观察区.

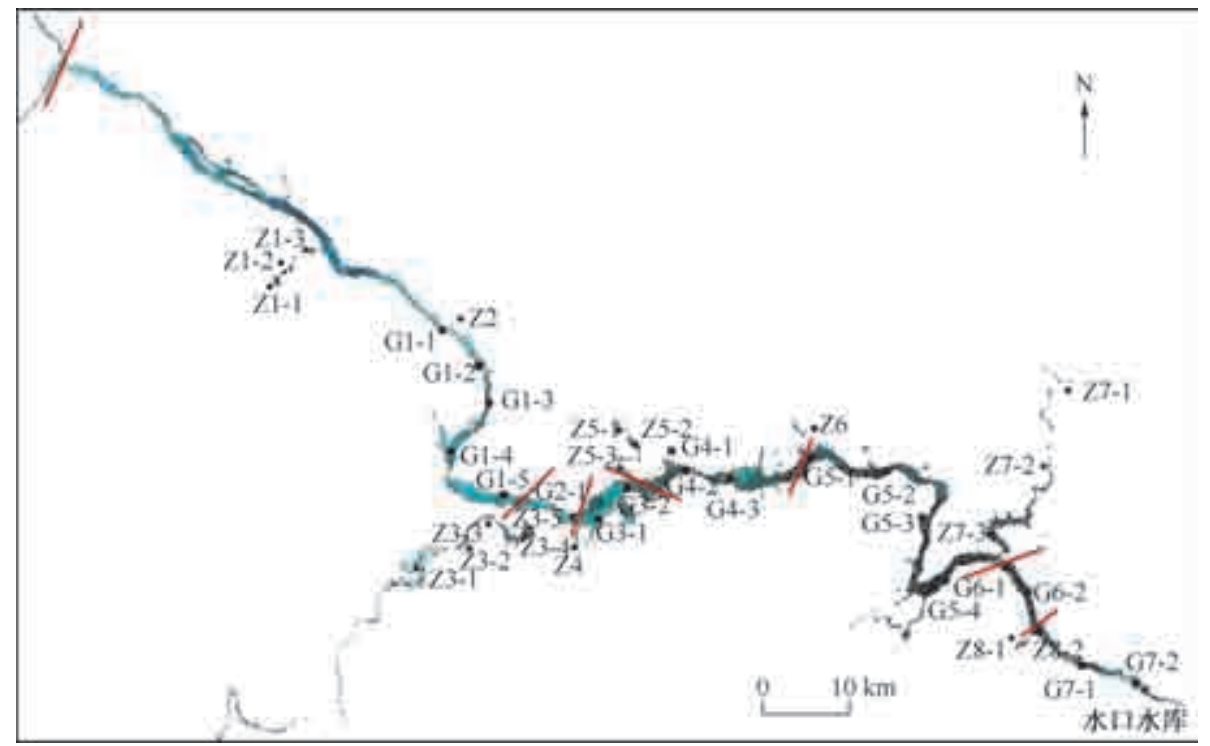

图 2 研究区子区布设

Fig. 2 Map of observation zones in the Shuikou Reservoir

\section{4 混合像元分解}

通过归一化光谱,运用约束线性光谱混合分析方法计算研究区域每种端元比例 ${ }^{[14]}$, 公式如下:

$$
\begin{gathered}
\overline{R_{b}}=\sum_{i=1}^{N} \overline{f_{i}} \overline{R_{(i, b)}}+e_{b} \\
\sum_{i=1}^{N} \overline{f_{i}}=1\left(\overline{f_{i}} \geqslant 0\right)
\end{gathered}
$$

式中, $\overline{R_{b}}$ 是波段 $b$ 某一像元的标准化反射比, $\overline{R_{(i, b)}}$ 是波段 $b$ 该像元 $i$ 中端元的标准化反射比, $\overline{f_{i}}$ 是端元的比 例, $e_{b}$ 是残差. 用最小二乘法计算出各个观察区影像像元的总丰度值. 最后应用公式: 凤眼莲面积 $=$ 影像栅格 大小的平方 $\times$ 丰度值, 计算出各观察点凤眼莲的面积.

\section{2 结果与分析}

\section{1 总体趋势分析}

将 2001-2009 年研究区域划分的 7 段干流分别统计发现, 随着时间的推移, 凤眼莲的暴发区逐渐向下 
游迁移. 2003、2004 年暴发区多在流域上游, 而 2007、2009 年暴发区在流域下游( 图 3 ). 从总体上看,上游凤 眼莲暴发多在 2006 年前,而下游多在 2006 年后.

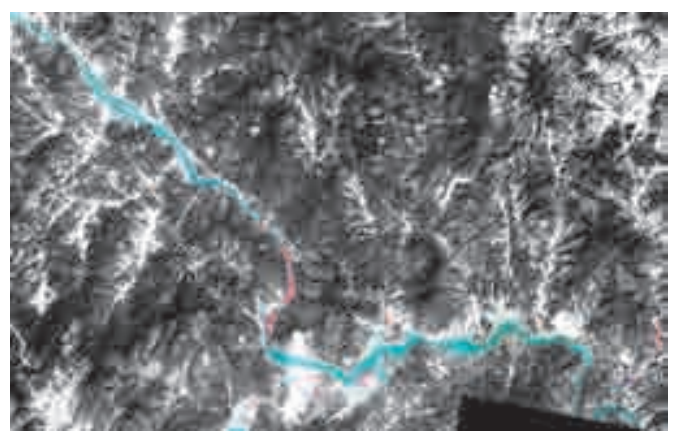

(a) 2003 年 12 月

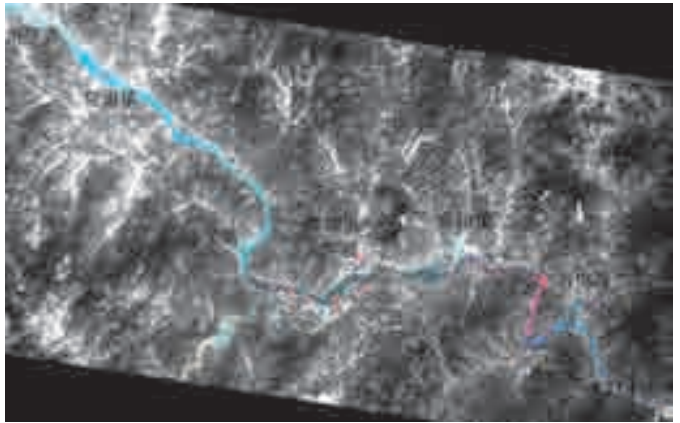

(c) 2007 年 1 月

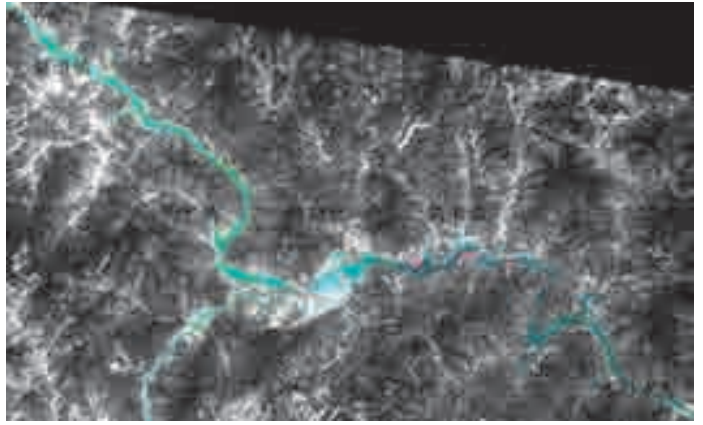

(b) 2004 年 12 月

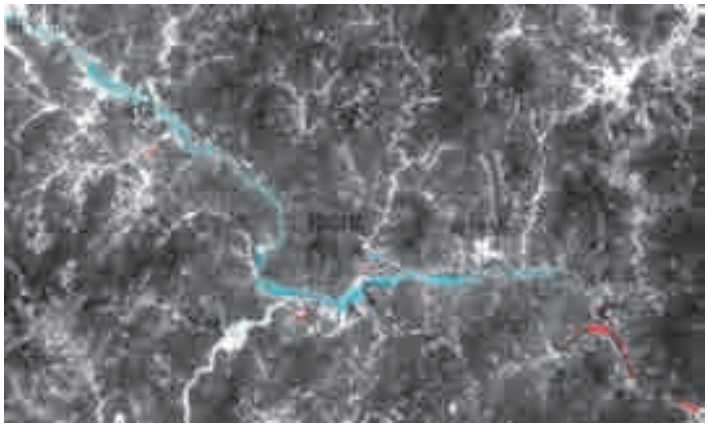

(d) 2009 年 6 月

图 3 研究区域凤眼莲暴发区分布 ( a b : CEBERS 卫星遥感影像; c d : Landsat TM 卫星遥感影像; 影像中红色部分为凤眼莲分布区域;影像 $\mathrm{a}$ 缺少该时间水口库区坝前的影像）

Fig. 3 The distribution of Eichhornia crassipes in survey region

( $\mathrm{a}, \mathrm{b}$ : CEBERS satellite imagery; $\mathrm{c}, \mathrm{d}$ : Landsat TM satellite imagery)

从 8 个支流情况看,支流 1 为凤眼莲最初出现的地点,且每年都有出现,2003 年前面积较小,但 2003 年 12 月之后面积增加, 从面积计算结果看出, 大部分时间该支流上的凤眼莲总面积都在 $10^{5} \mathrm{~m}^{2}$ 以上; 支流 3 (尤 溪) 在凤眼莲大暴发的 $2003 、 2004$ 、2009 年出现数量较多; 支流 5(武步溪) 分别在 2003 年和 2004 年的 12 月 份、2007 年的 1 月和 5 月份及 2009 年分布面积较大,2006 年虽有出现,但分布面积很小; 在研究范围内, 支 流 7 (古田溪) 凤眼莲于 2003、2004、2006、2007、2009 年均有出现, 且从研究数据看出 2003-2004 年的暴发 地区从上游逐渐向下游迁移,2006 年后该支流的凤眼莲仅在 Z7-3 出现,但除了 2007 年的 5-9 月,其分布面 积均在 $9 \times 10^{4} \mathrm{~m}^{2}$ 以下; 支流 8 仅在 2007 年 5 月份和 2009 年凤眼莲占据河道面积较大; 支流 2 、支流 4 、 支流 6 出现的次数不多且占据面积小. 从以上支流情况看出, 该研究区域除了支流 1 为源头外, 河流较长, 河 岸有居民居住的支流( 如支流 $3 、 5 、 7$ ) 也对凤眼莲的分布面积有重要影响. 此外, 干流中一些与支流交汇处较 接近的点也是受灾频率较多的地区, 根据金樑等的研究表明, 流域中成灾的凤眼莲并不是当地自然产生, 而 是从黄浦江的上游与其支流随水流而下并在某处聚集形成 ${ }^{[4]}$. 由此看出, 干流中的风眼莲大部分从支流漂 流而至. 因此,在河道中, 支流是凤眼莲源头治理的重点.

2004 年 10 月和 12 月对比,支流 1 凤眼莲面积变化不大; 支流 3 凤眼莲数量急剧增加; 支流 5 凤眼莲数 量增加, 在 12 月占据 1/2 河道; 支流 7 凤眼莲面积急剧减少, 仅 Z7-3 点在 12 月有极少量凤眼莲; 干流 $2 、 干$ 流 3 和干流 5 段凤眼莲面积增加.

2006 年支流 1 的风眼莲所占面积较多,特别是点 Z1-2 在 6-9 月占据整个河道, 1 月和 11 月份其它污染物占 据整个河道, 凤眼莲所占面积较少;点 Z1-1 在 1 月份有少量凤眼莲,但 6 月份消失, 8 月份再次出现,且面积逐月增 
加;Z1-3 点位于干流交界口, 河水具有流动性, 凤眼莲随水流漂向下游, 因此数量相对较少. Z4 点在 6 月份有大量 凤眼莲聚集在岸边. G3-2 点在 6 月 12 日的影像上有一定量的凤眼莲附着在岸边. 除此之外,2006 年干流总体趋势 是 1-9 月凤眼莲面积较少,11 月份部分观察点的凤眼莲面积大幅度增加(图 4、图 5).

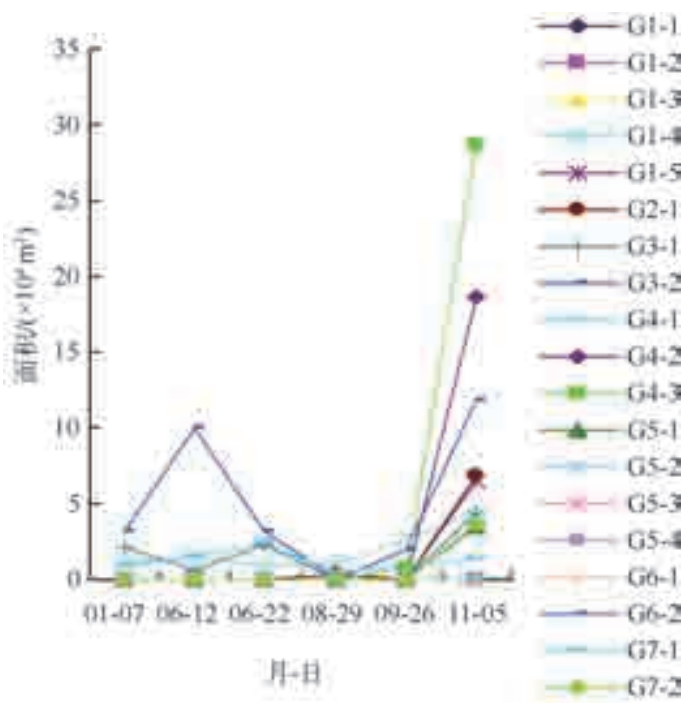

图 42006 年干流凤眼莲面积

Fig. 4 Area of Eichhornia crassipes in mainstream in 2006

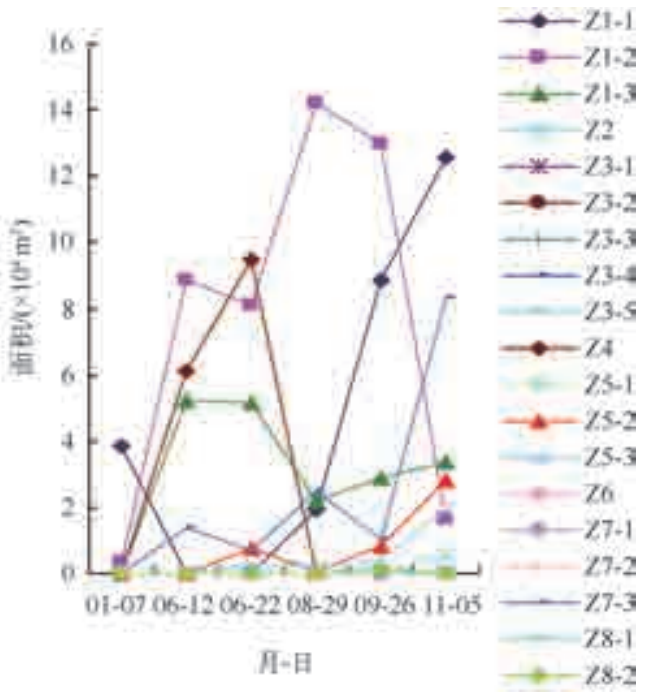

图 52006 年支流凤眼莲面积

Fig. 5 Area of Eichhornia crassipes in tributaries in 2006

2007 年凤眼莲的面积从总体趋势上看, 5 月份凤眼莲较多, $5-7$ 月下降, $8-9$ 月略微增加. 特别是点 G7-1、Z7-3 和 Z5-2, 在 5 月份占据整个河道, 至 7 月份骤减. 根据新华社报道 ${ }^{1}, 2007$ 年 3 月, 水口水电站的坝 头上凤眼莲泛滥, 5 月份针对凤眼莲进行了人工清理, 因此出现 5-7 月份河道中凤眼莲面积下降, $8-9$ 月 份面积略微上升的现象. 以支流的总体情况看, 除点 Z5-2、Z7-3 和 Z8-2, 其余观察点 1-5 月份凤眼莲面积减 少, 7-9 月份面积逐渐增加 (图 6); 以干流的总体情况看, 流域上游 (干流 1 干流 5) 在 1 月份凤眼莲面积 较 5 月份多, 下游 (干流 $6 \sim$ 干流 7 ) 1 月份面积较 5 月份少( 图 7), 说明凤眼莲具有漂流特性, 从上游漂流至 下游.

2009 年河道中凤眼莲所占面积相对往年更多, 特别是支流 1、支流 3、支流 8 和干流 6 、干流 7. 在 6 月份 点 G6-1 和点 G7-2 凤眼莲占据整个河道, 受灾水域长度近 $2 \mathrm{~km}$, 船舶通行严重受阻, 是凤眼莲泛滥最为严重 的一次, 但到 7 月份, 除点 Z3-3、点 Z5-2 和支流 8, 凤眼莲面积总体上大量减少, 因此认为在 6 月份凤眼莲暴 发后, 受灾区经过人工清理. 由于 2009 年人春来, 气温偏高, 使得原本生长快的凤眼莲加速繁殖. 导致 2009 年是 2004 年以来情况最严重的一年.

研究区域中凤眼莲面积在不同年份相同时间段有一定差异:2004 年 10 月约是 2005 年 10 月的 1.3 倍, 2007 年 8 月约是 2006 年 8 月的 1.65 倍以上, 2007 年 9 月约是 2006 年 9 月的 1.67 倍, 2009 年 7 月约是 2007 年 7 月的 2 倍.

总体来看, $2001-2009$ 年、2003 年 12 月和 2004 年的风眼莲所占面积较多, 2005 年和 2006 年除个别地 区, 凤眼莲总体面积不多, 2007 年凤眼莲面积再次上涨, 至 2009 年凤眼莲面积加倍上涨, 是 2004 年来情况 最严重的一年. 


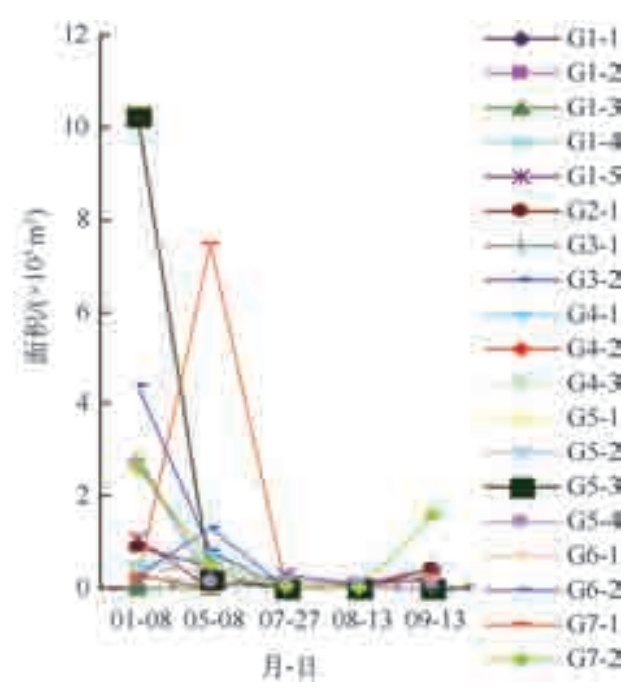

图 62007 年干流凤眼莲面积

Fig. 6 Area of Eichhornia crassipes in mainstream in 2007

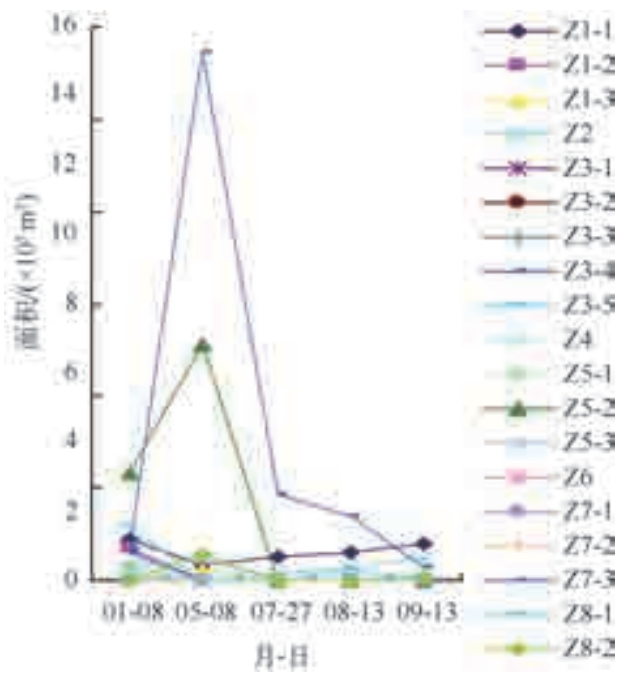

图 72007 年支流凤眼莲面积

Fig. 7 Area of Eichhornia crassipes in tributaries in 2007

\section{2 研究区域水质状况}

据调查,研究区域上游的沙溪河段是闽江流域工业最为集中的区域,沿途污染源密集,接纳大量畜禽养 殖、生活和工业废水,成为流域内污染最严重的河段. 根据 2005 年福建省政府转发的关于闽江流域水环境 保护规划文件显示,2004 年沙溪流域优于 III 类水质比例和水环境功能达标率均为 $61.5 \%$,主要超标项目有 氨氮、五日生化需氧量 $\left(\mathrm{BOD}_{5}\right)$ 、溶解氧. 研究区域水质环境功能均为 III 类标准, 为工业、渔业、景观娱乐用水 (表 1 $)^{[15]}$. 从南平市环境保护局发布的南平市水质状况看出,2006 年前研究区域及其上游水质基本未达 标,2006 年后水质大部分达标(表 2).

表 1 研究区域水环境功能区划

Tab. 1 Regionization of Water Environmental Function in survey region

\begin{tabular}{|c|c|c|c|c|c|c|c|}
\hline $\begin{array}{l}\text { 一级区 } \\
\text { 名称 }\end{array}$ & $\begin{array}{l}\text { 二级区 } \\
\text { 名称 }\end{array}$ & 起始断面 & 终止断面 & 水质现状 & $\begin{array}{l}\text { 水质 } \\
\text { 目标 }\end{array}$ & $\begin{array}{l}\text { 环境功 } \\
\text { 能类别 }\end{array}$ & $\begin{array}{l}\text { 区划 } \\
\text { 主要依据 }\end{array}$ \\
\hline $\begin{array}{l}\text { 闽江 中游延平区、 } \\
\text { 古田、闽清开发利用区 }\end{array}$ & - & 沙溪口坝址 & 水口水库坝址 & II IV & $\begin{array}{l}\text { 按一级 } \\
\text { 区划执行 }\end{array}$ & $\begin{array}{l}\text { 按二级 } \\
\text { 区划执行 }\end{array}$ & $\begin{array}{l}\text { 外福铁路及南平市区、 } \\
\text { 福州市开发区河段 }\end{array}$ \\
\hline 尤溪开发利用区 & - & 水东水库库尾 & 尤溪口 & II $\sim$ IV & $\begin{array}{l}\text { 按一级 } \\
\text { 区划执行 }\end{array}$ & $\begin{array}{l}\text { 按二级 } \\
\text { 区划执行 }\end{array}$ & 尤溪城区河段 \\
\hline $\begin{array}{l}\text { 武步溪延平、古田 } \\
\text { 保留区 }\end{array}$ & - & 大禄口 & 武步溪口 & II & II & III & 开发利用程度低 \\
\hline $\begin{array}{l}\text { 高洲溪尤溪、古田 } \\
\text { 保留区 }\end{array}$ & - & 源头 & 高洲溪口 & II & II & III & 开发利用程度低 \\
\hline $\begin{array}{l}\text { 古田溪屏南、古田、闽 } \\
\text { 清保留区 }\end{array}$ & - & 长桥 & 古田溪口 & II III & III & III & 开发利用程度低 \\
\hline $\begin{array}{l}\text { 闽江中游延平区、古 } \\
\text { 田、闽清开发利用区 }\end{array}$ & $\begin{array}{l}\text { 闽江延平区、 } \\
\text { 古田、闽清渔 } \\
\text { 业用水区 }\end{array}$ & 十里庵 & 水口坝址 & III & III & III & 渔业、景观娱乐用水 \\
\hline 尤溪开发利用区 & $\begin{array}{l}\text { 尤溪工业用 } \\
\text { 水区 }\end{array}$ & 水东水库坝址 & 尤溪口 & III $\sim$ IV & III & III & 尤溪工业、渔业用水 \\
\hline
\end{tabular}


表 2 南平市水域水质状况

Tab. 2 Water quality conditions of rivers in Nanping City

\begin{tabular}{lcrrrrrrr}
\hline 达标率 & 河流(河段) & 2004 年 & 2005 年 & 2006 年 & 2007 年 & 2008 年 & 2009 年 & 2010 年 \\
\hline 水域功能达标率 $/ \%$ & 闽江南平段 & 76.2 & 66.7 & 100.0 & 100.0 & 100.0 & 96.7 & 100.0 \\
& 建溪 & 96.4 & 96.4 & 100.0 & 100.0 & 100.0 & 100.0 & 98.9 \\
& 富屯溪 & 91.7 & 100.0 & 100.0 & 100.0 & 100.0 & 100.0 & 100.0 \\
& 总计 & 88.1 & 90.3 & 100.0 & 100.0 & 100.0 & 99.4 & 99.4 \\
I ～III类水质 & 闽江南平段 & 85.7 & 83.3 & 100.0 & 100.0 & 100.0 & 96.7 & 100.0 \\
达标率/\% & 建溪 & 96.4 & 97.6 & 100.0 & 100.0 & 100.0 & 100.0 & 98.9 \\
& 富屯溪 & 81.3 & 90.0 & 93.3 & 93.3 & 96.7 & 100.0 & 100.0 \\
& 总计 & 87.8 & 91.7 & 98.6 & 98.6 & 99.4 & 99.4 & 99.4 \\
\hline
\end{tabular}

\section{3 研究区域凤眼莲频发成因分析}

考虑到 2006 年前上游污染较严重, 导致上游水质恶化,这可能是上游凤眼莲暴发多在 2006 年前的一个 原因. 研究发现, 水环境中的营养水平对风眼莲的生长繁殖有明显影响, 当水体中有足够的氮、磷养分, 并具 备合适的光照, 温度和氧气等外因时, 就会引发凤眼莲的快速生长 ${ }^{[16-17]}$. 并且, 凤眼莲的耐受性强, 在水质很 差的环境下 (如工业废水) 也能正常生长, 其在污染水体中的生长速度为天然水体中的 2 倍, 并能有效地竞 争并排斥其他植物物种, 形成大面积的纯种群 ${ }^{[18-19]} .2006$ 年后, 凤眼莲多在下游暴发, 可能是上游的凤眼莲 随着水流往下漂流的原因.

资料显示 (1) 闽江流域有多个大中型水电站,还有大量无序开发的小水电站,根据水利部门提供的信息, 至 2004 年初, 南平市已建成各类水电站七百多座. 过度和不合理的水电开发使自然急流变为人工平湖, 河 流流速变缓, 自净能力降低, 污染物淤积, 水质变差, 库区富营养化程度加剧. 邬红娟等 ${ }^{\left[{ }^{[0]}\right.}$ 认为湖泊、河流和 水库的水滞留时间对浮游植物生物量和生产力有很大影响, 当流速超过浮游植物繁殖速率, 生物量的积累 和生产力就会流失. 再加上研究区域多为渔业养殖用水, 河道间有较多的养殖网箱, 这不仅促进水流变缓, 还有利于凤眼莲在网箱周围生长. 金樑等以上海黄浦江为研究区, 发现凤眼莲在水体中的固着机制与河流 的整齐度以及河道内其它水生植物的分布存在很大关系, 河岸不整齐, 近岸边生有许多水生植物的河道和 流水较慢的小河流易于成为凤眼莲生长和繁殖的发源地 ${ }^{[4,21]}$.

对照实际情况, 观察风眼莲出现频率较多的地点 (表 3), 发现这些观察点的共性: (1) 沿岸多为村庄或乡 镇, 常有居民生活污水和农业污水排人河流, 且多处河道进行渔业养殖, 使得水体氮、磷元素过多, 水体富营 表 $32001-2009$ 年各观察点出现凤眼莲的频率

Tab. 3 The frequency of occurrence of Eichhornia crassipes from 2001 to 2009

\begin{tabular}{|c|c|c|c|c|c|c|c|c|c|c|c|}
\hline 观察点 & 次数 & 频率/\% & 观察点 & 次数 & 频率/\% & 观察点 & 次数 & 频率/\% & 观察点 & 次数 & 频率/\% \\
\hline $\mathrm{Z} 1-1$ & 20 & 7.91 & G1-5 & 8 & 3.16 & Z8-2 & 5 & 1.98 & G1-2 & 2 & 0.79 \\
\hline $\mathrm{Z} 1-3$ & 18 & 7. 11 & G4-1 & 8 & 3.16 & G5-2 & 4 & 1.58 & G4-2 & 2 & 0.79 \\
\hline G1-4 & 16 & 6.32 & G5-1 & 8 & 3.16 & G6-1 & 4 & 1.58 & $\mathrm{Z4}$ & 2 & 0.79 \\
\hline G3-1 & 14 & 5.53 & Z5-3 & 8 & 3.16 & G6-2 & 4 & 1.58 & Z6 & 2 & 0.79 \\
\hline G3-2 & 14 & 5.53 & $\mathrm{Z} 2$ & 7 & 2.77 & Z3-1 & 4 & 1.58 & Z7-1 & 2 & 0.79 \\
\hline Z7-3 & 14 & 5.53 & G4-3 & 6 & 2.37 & G7-1 & 3 & 1.19 & G1-1 & 1 & 0.40 \\
\hline G7-2 & 11 & 4.35 & G5-4 & 6 & 2.37 & Z3-3 & 3 & 1.19 & G1-3 & 1 & 0.40 \\
\hline $\mathrm{Z} 5-2$ & 11 & 4.35 & Z3-5 & 6 & 2.37 & Z5-1 & 3 & 1.19 & Z3-2 & 1 & 0.40 \\
\hline $\mathrm{Z} 1-2$ & 10 & 3.95 & G5-3 & 5 & 1.98 & $\mathrm{Z7}-2$ & 3 & 1.19 & & & \\
\hline G2-1 & 9 & 3.56 & $\mathrm{Z} 3-4$ & 5 & 1.98 & Z8-1 & 3 & 1.19 & & & \\
\hline
\end{tabular}

(1) 《福建省人民政府办公厅转发省环保局关于闽江流域水环境保护规划的通知》. 
养化. 根据蔡雷鸣 ${ }^{[13]} 2001$ 年与 2004 年对水口库区水质指标的监测结果显示, 2004 年水中的总氮、总磷含量 均超过 III 类标准. 同时结合福州监测站 2006-2009 年对水口库区雄江镇的水质监测结果, 2007-2009 年个 别月份的总磷含量超标. 由此可见,库区部分地区已呈现富营养化趋势. (2) 河道结构较为复杂, 河流沿岸角 落处容易成为死角, 河水在此处不流动.

2001 年 1 月起,研究区域内就有个别地区存在凤眼莲,但数量极少. 2001 年 5 月水口坝前已覆盖有少量 凤眼莲. 2003 年 12 月研究区域凤眼莲大面积暴发,多段河道被凤眼莲占据. 此后, 2003、2004、2007、2009 年 均为凤眼莲扩散较严重的年份, 特别是 2004 年和 2009 年. 中国气象科学数据库中获得的南平市气象资料表 明,2003、2004、2007、2009 年正好是年降雨量相对较少的年份 (表 4), 由于降雨量小、水流量小、流速较缓, 有利于凤眼莲固着生长, 并且水体富营养化浓度升高, 导致凤眼莲快速生长. 同时 2003、2004、2007、2009 年 也是日照时数或年平均气温相对高的年份, 由于凤眼莲性喜光, 适应于热带、亚热带气候, 在光照强、温度为 $25 \sim 35^{\circ} \mathrm{C}$ 气候条件下时, 植株成长迅速 ${ }^{[15,22]}$.

表 $42001-2009$ 年研究区气象数据

Tab. 4 Meteorological data in survey region from 2001 to 2009

\begin{tabular}{lccccccccc}
\hline 气象资料 & 2001 年 & 2002 年 & 2003 年 & 2004 年 & 2005 年 & 2006 年 & 2007 年 & 2008 年 & 2009 年 \\
\hline 年降雨量 $/ \mathrm{mm}$ & 1847.8 & 1861.1 & 1002.3 & 1319.4 & 1815.3 & 1896.7 & 1271.0 & 1360.9 & 1359.6 \\
年日照 $/ \mathrm{h}$ & 1727.4 & 1685.3 & 2131.1 & 1988.2 & 1651.7 & 1667.5 & 1862.6 & 2044.7 & 2015.4 \\
年平均气温 $/{ }^{\circ} \mathrm{C}$ & 20.06 & 20.55 & 20.83 & 20.12 & 19.84 & 20.10 & 20.43 & 19.90 & 20.18 \\
\hline
\end{tabular}

\section{3 总结与讨论}

本文运用 2001-2009 年的卫星遥感影像,对比分析得出水口水库中凤眼莲的时空分布情况：

1) 2001 年水口水库已有少量凤眼莲存在,2003 年 12 月凤眼莲已在水库库区大量暴发,其中 2004 年、 2007 年、2009 年凤眼莲占据河道面积较多,特别是 2004 年和 2009 年.

2) 每年凤眼莲数量较多的时间段出现在 5、6 月份和 9-12 月份. 原因为 5、6 月份凤眼莲大量繁殖, 影 响水上交通,当地政府和环保部门针对其进行人工清理,使之数量减少. 但由于清理未彻底,剩余的风眼莲 继续生长,使 9-12 月份凤眼莲再次泛滥.

3 ) 随着时间的推移, 凤眼莲的暴发区逐渐向下游迁移. 从总体上看, 上游凤眼莲暴发多在 2006 年前, 下游凤眼莲暴发多在 2006 年后.

4) 支流应该是凤眼莲源头治理的重点. 支流 1 是凤眼莲最先出现的地点, 也是出现次数最多的地点, 可以将其认为是凤眼莲最初产生点之一, 首先要对支流 1 的凤眼莲进行重点清除. 除此之外, 河流较长、河 岸边有居民居住的支流, 如支流 3(尤溪) 、支流 5(武步溪) 和支流 7(古田溪) 凤眼莲出现的频率高、面积大, 对研究区域凤眼莲的面积有重要影响, 因此, 应将支流 3、5、7 视为凤眼莲重要来源,采取相应措施.

5 ）凤眼莲泛滥有多方面原因,除了客观因素 (闽江上游出现罕见的少雨干早、气温偏高的气候现象), 沿江一带养殖业的发展、工业废水、人类生活污水的排放造成水体氮、磷元素过多以及过度和不合理的水电 开发使自然急流变为人工平湖,河流流速变缓等都是重要原因.

若要预防凤眼莲年年泛滥, 应每年都对凤眼莲积极清理, 特别是支流和易形成死角的岸边, 建议在前一 年冬天开始作业, 可达到事半功倍的效果. 同时对沿岸排放的污水进行达标处理,加强研究源头综合治理措 施,推广库区上游低污染的生产方式. 根据福建省人民政府的要求,2010 年闽江南平段水域功能区达标率应 在 95\% 以上,2020 年全流域水质全面稳定达到或优于功能分区的环境质量标准. 为达到研究区域水环境的 保护,应针对研究区域上游及其周边, 建设生态功能保护区,力争使流域的源头区、重要水源涵养区、水土保 持重点预防保护区, 重点监督区和重要渔业水域等重要生态功能区的生态系统和生态功能得到保护与恢复; 在切实抓好现有自然保护区建设与管理的同时,建设一批新的自然保护区,使各类良好自然生态系统及重要 物种得到有效保护; 建立、健全生态环境保护监管体系, 使生态环境保护措施得到有效执行, 重点资源开发区 的各类开发活动严格按规划进行,生态环境破坏恢复率有较大幅度提高; 加强生态示范区和生态农业县建设, 
并继续开展城镇环境综合整治, 进一步加快能源结构调整和工业污染源治理 ${ }^{[22]}$, 重点完成以下工程:

1) 养殖污染整治: 严格落实畜禽养殖 “两禁区” 规定, 全面完成禁养区内养殖场搬迁拆除工作, 加快禁 养区外规模养殖场的污染治理, 特别是研究区域上游的畜禽污染综合整治, 并加强先进技术推广, 防止出现 污染反弹. 此外, 研究区域多处进行渔业养殖, 应加强重点渔场及其他渔业水域等重要水生资源繁育区的保 护,严格渔业资源开发的生态环境保护监管.

2) 工业污染整治: 结合污染减排, 加强工业污染整治, 加快推进工业开发区、重点行业企业污染治理, 针 对研究区域上游沙溪流域为闽江流域工业最为集中的区域, 应加强工业污染排放监控, 强化对污染源的监 督管理,并停止一切产生严重环境污染的工程项目建设.

3) 生态环境建设与保护: 以保障流域生态功能为目标, 推进矿山整顿、水土流失治理、生态林保护和自 然保护区建设, 整顿规范河砂开采, 落实水电站生态下泄流量要求, 对于布局不合理, 影响生态平衡的水库 进行整改或拆除. 加强库区水葫芦及漂浮垃圾的清理工作, 开展小流域污染整治, 大力推进农村环境整治, 引导和推动县市及乡村开展生态创建工作.

\section{4 参考文献}

［1］汪凤娣. 外来人侵物种凤眼莲的危害及防治对策. 黑龙江环境通报, 2003, 27(3) : 21-23.

[ 2 ] 任明迅. 水生植物风眼莲的种内基因型差异与人侵模式 [学位论文]. 北京: 中国科学院植物研究所, 2006.

[ 3 ] 庄先林, 郑 树, 吴世铭等. 福建省水口库区水葫芦专项整治研究. 海峡科学, 2007, (7) : 76-77.

[ 4 ] 金 樑, 王晓娟, 高 雷等. 上海市凤眼莲种群的时空分布及控制对策. 生态学杂志, 2005, 24(12): 1454-1459.

[ 5 ] 王 云, 周国庆, 周国峰等. 洞庭湖区水葫芦分布及危害的评价. 草业科学, 2008, 25(3): 97-101.

[6] 王 瑞, 王印政, 万方浩. 外来人侵植物一年蓬在中国的时空扩散动态及其潜在分布区预测. 生态学杂志, 2010, (6) : 1068-1074.

[ 7 ] Cavalli RM, Laneve G, Fusilli L et al. Remote sensing water observation for supporting Lake Victoria weed management. Journal of Environmental Management, 2009, 90 : 2199-2211.

[ 8 ] 章 荣, 卢剑波. 外来人侵物种互花米草 (Spartina alterniflora) 及凤眼莲 (Eichhornia crassipes) 的遥感监测研究进 展. 科技通报, 2010, 26(1) : 130-137.

[ 9 ] 沈永明, 刘咏梅, 陈全站. 江苏沿海互花米草盐沼扩展过程的遥感分析. 植物资源与环境学报, 2002, 11(2): 33-38.

[10] Everitt JH, Yang C, Escobar DE et al. Using remote sensing and spatial information technologies to detect and map two aquatic macrophytes. Journal of Aquatic Plant Management, 1999, 37 : 71-80.

[11] Venugopal G. Monitoring the effects of biological control of water hyacinths using remotely sensed data: A case study of Bangalore, India. Singapore Journal of Tropical Geography, 1998, 19(1) : 91-105.

［12］袁信芳, 施华宏, 王晓蓉. 太湖着生藻类的时空分布特征. 农业环境科学学报, 2006, 25 (4) : 1035-1040.

[13] 蔡雷鸣. 福建闽江水口库区飘浮植物覆盖对水体环境的影响. 湖泊科学, 2006, 18(3) : 250-254.

[14] Adams JB, Smith MO, Johnson PE. Spectral mixture modeling: A new analysis of rock and soil types at the Viking Landerl site. Journal of Geophysical Research, 1985, 91 (B8) : 8098-8112.

[15] 程永隆等. 福建省水(环境)功能区划. 福建: 福建省水利厅, 福建省环境保护局, 2004.

[16] 杨红玉, 张江山, 众 川等. 水环境中氮、磷营养水平对水葫芦生长的影响. 安徽农学通报, 2008, 14 (23): 67-71.

[17］张秋芳, 刘 波, 官雪芳等. 水葫芦对氮磷营养的需求及分布规律初探. 中国农学通报, 2007, 23(5): 387-389.

[18］齐玉梅, 高伟生. 凤眼莲净化水质及其后处理工艺探讨. 环境科学进展, 1999, 7(2): 136-140.

[19］杨凤辉.上海黄浦江风眼莲灾害的发生机理及控制对策初探. 复旦学报, 2002, 41(6) : 599-603.

[20] 邬红娟, 郭生练. 水库水文情势与浮游植物群落结构. 水科学进展, 2001, 12(1) : 51-55.

[21] 孙 超, 陈振楼, 毕春娟等. 黄浦江上游水源保护区不同河段水葫芦最佳治理对策. 杂草科学, 2008, (3): 14-17.

[22] 新华社. 全国生态环境保护纲要 [EB/OL]. http: //www. people. com. cn/GB/channel1/907/20001222/358911. html. 